\title{
The Mother's Role in Improving the Oral and Dental Health of their Children: Application of Planned Behavior Theory
}

\author{
BAHAREH KABIRI ${ }^{1}$, ALI REZA HIDARNIA2², MEHDI MIRZAEI ALAVIJEH ${ }^{3}$, MOHAMMAD ESMAEEL MOTLAGH $^{4}$ \\ ${ }^{1}$ Health Education and Health Promotion, faculty of medical Sciences, Tarbiat Modares University, Tehran, Iran. E-mail: \\ b.kabiri@modares.ac.ir \\ ${ }_{2}$ Professor, Department of Health Education and Health Promotion,faculty of medical Sciences, Tarbiat Modares University, Tehran, Iran. \\ E-mail: hidarnia@modares.ac.ir \\ ${ }^{3} \mathrm{PhD}$ of Health Education and Promotion, Islamic Studies and Health Sciences Interdisciplinary Research Center, Kermanshah University of \\ Medical Sciences, Kermanshah, Iran. E-mail: mehdimirzaiea@yahoo.com \\ ${ }^{4}$ School of Medicine, Jundishapur University of Medical Sciences, Ahvaz, Iran.E-mail: Dr.motlagh.ms@gmail.com \\ *Corresponding author E-mail: hidarnia@modares.ac.ir
}

\begin{abstract}
Introduction: It is necessary to identify the factors affecting the behaviors of the parents, especially mothers, in improving children's oral and dental health according to the theories of behavior change. This research aimed at determining the role of mothers in improving the oral and dental health of the children on the basis of the planned behavior theory.

Materials \& Methods: This was a descriptive-analytical, cross-sectional study. The research population included 240 subjects selected through the stratified random sampling from the mothers in the city of llam, Iran. The data collection tool was a questionnaire, which consisted of two sections: seven demographic and background questions, five items about attitude, four items about subjective norms, and five items concerning behavioral intention, which were completed as self-report. The collected data were analyzed using SPSS-21 software through descriptive and analytical tests such as independent t-test, linear regression, and Pearson correlation coefficient that were examined and had a significant level of 0.05 .

Findings: The participants' age ranged from 20 to 44 (mean=5.67 \pm 31.8 ). The linear regression test indicated the structure of attitude $(B=0.135, P<0.001)$, perceived behavioral control $(B=0.398, P<0.001)$, subjective norms $(B=$ $0.236, \mathrm{P}<0.001$ ), and explained the $46 \%$ of the behavioral intention variance.

Conclusion: Taking into account the impact of the attitude structure on the behavioral intention predicting, therefore, this structure should be employed in designing the preventive training programs in the framework of the theory of the planned behavior.

Keywords: Attitude, Theory of Planned Behavior, Mothers, Dental Health.
\end{abstract}

\section{INTRODUCTION}

One of the health assessment criteria of the people in a society is examining their oral and dental health (1).

The mouth is the mirror to the body and teeth are the most important parts of the body. Teeth are responsible for chewing, talking, beauty, and protection of the periodontal tissues (2).

Oral health in dentistry means developing and maintaining effective preventive habits in people (3).

In accordance with the World Health Organization $(\mathrm{WHO})$, oral health enables a person to talk, socialize, and eat without any illness or anxiety. The foundation of the health and welfare of the body is its oral health, which influences the quality of life and the general status of the body (4).

The American Dental Association (ADA) provided a definition of oral health in 2001 that was very well-received. This association in their definition indicated that oral health is a state of the oral structure and tissue that includes the social, psychological, and physical welfare of a person and helps to enjoy life and it enables the person to talk, eat, and socialize with others (5).

A child's primary teeth (milk teeth) normally start to come in (erupt) at 6 months of age and their set completes at 2.5 years old. When the child is 6 years old, their permanent teeth start growing and gradually they replace the primary teeth. Growth of the permanent teeth continues until the age of 12 years old, therefore, the child might still have few milk teeth at this age. The primary teeth are responsible for chewing food, maintaining the appearance, the beauty of the face, and talking. However, their most important responsibility is to preserve the space required for the growth of the permanent teeth. Thus, by taking care of the primary teeth of the child, you can expect the child's permanent teeth to grow and develop properly $(6,7)$.

The American Academy of Pediatrics (AAP), stressed that specialized care for identifying the risk factors affecting the oral and dental health in all children must start before the age of 6 months (8). The parents, are the first social forces that influence the child's growth and health at their early ages and they have a crucial role in developing healthy habits, and continuance of the healthy behavior in children and preventing diseases (9).

The parents teach oral and dental health to their children and in the future, the parents' awareness, attitude, and beliefs will impact the child's oral and dental health. However, the parents' have poor information regarding the importance of the primary teeth and they do not consider them to be very important (10-12).

Improving the behaviors pertinent to the oral and dental health in the people requires an understanding of the basic factors that has a vital role in the decisions they make regarding the proper behaviors. This requirement will be met merely by employing a theory for identifying the 
mediation factors in the behaviors pertinent to oral and dental health (13).

The theory of the planned behavior is numbered among the most famous theories in this regard. The theory of the planned behavior provides a framework for the regular and fundamental investigation of the problems pertinent to making the behavior-related decision (14).

According to this theory, the most important determinant of a person's behavior is behavioral intention. The intention arises from three factors such as attitude, subjective norms, and perceived behavioral control. A person's belief in the results of their behaviors and evaluations leads to the creation of attitude. The subjective norms are affected by the person's beliefs regarding others' expectations and the person's motivation for meeting those expectations. The perceived behavioral control is a degree of the feelings in a person regarding that to what extent they are in control of displaying or not displaying a behavior (14). This theory elaborates on approximately 40 percent of the relationship between intention and behavioral health. Therefore, this theory is claimed to have a potential capacity in developing the inferences of behavior change (15).

Accordingly, the present research was conducted to determine the role of the mothers in improving the oral and dental health of children on the basis of the theory of the planned behavior.

\section{MATERIALS \& METHODS}

This is a descriptive-analytical cross-sectional study. It was carried out on 240 mothers with children between 6-month to 1 -year-old in the city of llam in 2018-2019. Taking into consideration the validity level of $98 \%(\alpha=0.05)$, and precision (0.2), the sample size was estimated to be 240 $(n=240)$.

The mothers went to 18 health centers in the city of Ilam (located in the South of Iran) were selected through stratified random sampling and proportionate to the total population.

The inclusion criteria for the research were having children with the age ranging from 6 months to 1 year old, having healthy children, having health record, having the minimum literacy to read and write. The data were collected based on the questionnaire created by the researcher by interviewing the mothers. To examine the validity of the questionnaire, it was investigated by 10 specialists in the field of dentists' health education and health promotion, and the required revisions were applied. Furthermore, the Cronbach's Alpha was employed for assessing the reliability of the questionnaire and the Cronbach's Alpha was investigated and approved for attitude structure $(\alpha=0.71)$, perceived behavioral control $(\alpha=0.78)$, the structure of the subjective norms $(\alpha=0.76)$, the behavioral intention structure $(\alpha=0.70)$.

The questionnaire comprised two sections. The first section included 7 questions such as demographic and background questions of the participants, and the second section included structures such as the planned behavior model, 5 items for attitude, 5 items for the perceived behavioral control, 4 items for subjective norms, and 5 items for behavioral intention. All these questions were measured on the basis of the Likert scale ranging from 1 (completely disagree) to 5 (completely agree).

The data were analyzed using the statistical software of SPSS through statistical tests such as frequency distribution, Pearson correlation coefficient, and linear regression analysis.

The present research is a part of the Doctoral Dissertation that was carried out through the financial support of the Tarbiat Modares University of Tehran and upon observing the Ethical Considerations.

\section{FINDINGS}

The participants' age ranged from 20 to 44 (mean=5.67 \pm 31.8 ). Among the participants, 105 subjects (43.7) were high school drop-outs, 135 subjects (56.3) had academic education (Table 1). Among the various structures, the participants achieved the highest score in the behavioral intention structure by obtaining $29 \%$ of the maximum acceptable score (Table 2). Among the different structures of the theory, the structure of the perceived behavioral control and the behavioral intention had the highest correlation $(r=0.562, p<0 / 001)$ (Table 3$)$. Besides, the structure of the attitude had higher predictive potential than other structures with respect to the behavioral intention and it predicted 9.1 percent of the behavioral intention variance (Table 4).

Table 1: The Demographic \& Background Variables of the Participants of the Research:

\begin{tabular}{|l|l|l|l|l|l|l|l|l|l|l|l|l|}
\hline & \multicolumn{3}{|l|}{ Mother's Education } & \multicolumn{2}{l|}{ Father's Education } & \multicolumn{2}{l|}{ Mother's Occupation } & \multicolumn{2}{l|}{ Father's Occupation } \\
\hline & $\begin{array}{l}\text { High } \\
\text { School } \\
\text { Drop- } \\
\text { Out }\end{array}$ & $\begin{array}{l}\text { University } \\
\text { Education }\end{array}$ & $\begin{array}{l}\text { High } \\
\text { School } \\
\text { Drop- } \\
\text { Out }\end{array}$ & $\begin{array}{l}\text { High } \\
\text { School } \\
\text { Diploma }\end{array}$ & $\begin{array}{l}\text { University } \\
\text { Education }\end{array}$ & Housewife & Employee & $\begin{array}{l}\text { Business } \\
\text { Person }\end{array}$ & Retired & Employee & $\begin{array}{l}\text { Business } \\
\text { Person }\end{array}$ \\
\hline Number & 105 & 135 & 27 & 78 & 135 & 175 & 46 & 19 & 3 & 232 & 5 \\
\hline Percentage & 43.7 & 56.3 & 11.2 & 32.5 & 56.3 & 72.9 & 19.2 & 7.9 & 1.3 & 96.7 & 1.2 \\
\hline
\end{tabular}

Table No. 2: Mean Scores of Various Structures of the Theory of Planned Behavior:

\begin{tabular}{|l|l|l|l|l|l|l|}
\hline Variable & Mean & $\begin{array}{l}\text { Standard } \\
\text { Deviation }\end{array}$ & $\begin{array}{l}\text { Minimum Score } \\
\text { Obtained }\end{array}$ & $\begin{array}{l}\text { Maximum Score } \\
\text { Obtained }\end{array}$ & Score Range & $\begin{array}{l}\text { Mean Percentage of } \\
\text { the Maximum Score }\end{array}$ \\
\hline Attitude & 21.45 & 2.5 & 14 & 25 & $5-25$ & 2.5 \\
\hline $\begin{array}{l}\text { Perceived Behavioral } \\
\text { Control }\end{array}$ & 21.5 & 3.1 & 8 & 25 & $5-25$ & 3.1 \\
\hline Behavioral Intention & 19.8 & 3.2 & 7 & 25 & $5-25$ & 3.2 \\
\hline Subjective Norm & 11.04 & 2.88 & 4 & 15 & $4-20$ & 2.8 \\
\hline
\end{tabular}


Table No. 3: The Correlation among Various Structures of the Theory of Planned Behavior:

\begin{tabular}{|l|l|l|l|l|}
\hline Structures & Attitude & Perceived Behavioral Control & Behavioral Intention \\
\hline Attitude & 1 & ${ }^{* \star} 0.437$ & 0.335 & Subjective Norm \\
\hline $\begin{array}{l}\text { Perceived } \\
\text { Behavioral Control }\end{array}$ & ${ }^{* \star} 0.437$ & 1 & ${ }^{* *} 0.652$ & \\
\hline Behavioral Intention & ${ }^{\star \star} 0.335$ & ${ }^{* \star} 0.562$ & 1 & ${ }^{* \star} 0.447$ \\
\hline Subjective Norm & ---- & ${ }^{* \star} 0.447$ & ${ }^{* \star} 0.429$ & 1 \\
\hline
\end{tabular}

** Significance at level $0.01,{ }^{*}$ Significance at level 0.05

Table No. 4: The Predictive Potential of Various Structures of the Theory of Planned Behavior in Comparison to the Tooth Decay Preventive Behavior:

\begin{tabular}{|l|l|l|l|l|l|l|l|}
\hline Variable & B & SE & Beta & T & R2 & Pependent \\
\hline Attitude & 171 & 0.73 & 0.135 & 2.3 & 46.25 & $\begin{array}{l}\text { Behaviable } \\
\text { Intention }\end{array}$ \\
\hline $\begin{array}{l}\text { Perceived } \\
\text { Behavioral Control }\end{array}$ & 405 & 0.65 & 0.395 & 6.5 & 001 & 0.001 \\
\hline Subjective Norm & 262 & 0.65 & 0.236 & 4.06 & & 0.001 \\
\hline
\end{tabular}

\section{DISCUSSION}

The present research was conducted aiming at determining the factors affecting the mother's behavioral intention in improving the oral and dental health of their 6-month to 1year-old children according to the framework of the theory of planned behavior. The results indicated that among the effective structures on behavioral intention on the basis of this theory, the structures of attitude and subjective norms were significantly effective, respectively. Some studies had similar results. In the study conducted by Bashirian et al. (3), the structures of attitude, subjective norm, and perceived behavioral control were the strongest predictor structures (16). In other studies, the structure of the subjective norm was identified as the weakest predictor $(18,17)$. In the present research, the structure of the behavioral intention was considered as the dependant variable, however, in some studies, it is considered as the dependent variable and the impact of other structures on this variable is examined. Therefore, this can be considered as one of the differences between this study and the former studies (19).

In general, the theory of the planned behavior could predict 46.25 percent of the behavioral intention variance. In other studies, the structures such as attitude, subjective norms, and perceived behavioral control predicted 66.2 and 63 percent behavioral intention variance in the field of oral and dental health $(21,20)$. This difference in the amount can be pertinent to the cultural and social background of the respective people. The results of the present research revealed that the most important factor in the behavioral intention of the oral and dental health by the mothers in accordance with the theory of the planned behavior is the attitude that by focusing on them in the educational programs, we can take measures more effectively.

\section{CONCLUSION}

Taking into account that the most crucial factor in the behavioral intention of the oral and dental health in children of a family on the basis of the theory of the planned behavior in the present research was attitude, therefore, the results of the present research must be employed in designing preventive educational programs.

Acknowledgment: The present research is a part of the Doctoral Dissertation that was carried out through the financial support of the Tarbiat Modares University of Tehran and the ethical approval ID of
IR.MODARES.REC.1398.021. Thus, I hereby express my deepest gratitude to the authorities of the university and the health centers and all mothers of the city of Ilam, especially the participants of the present research.

\section{REFERENCES}

1. Mohammad Nejad A, Shariat A,Baygjani G,Abotalebbi Gh. Saveh oral health status of primary school children in 2009 scientific. Journal of Gorgan College Nursing \& Midwifery 2013;1:74-80

2. Ashrafizadeh S C, Surrey H, Ashrafzadeh M. Reliability the oral health status of 12-year-oldDMFT school students in Ahwaz. Ahvaz Medical Journal 2002;34:60-66

3. Basir L, Khan Masghede M, Dashtb ozorg B. [Effect of repeated oral health educationon health indicators 9 and 10 year old students in Ahvaz in 2003]. J Med 2008;2:219-29

4. World Health Organization. Oral health surveys: basic methods. World HealthOrganization; 2013.

5. canadian dental association definition oforal health among items endorsed by board ofgovernors . communique 2001; 4:1-15.

6. Naderifar M, Ghaljaei F, Akbarizadeh MR. Determination of the mothers' practice aboutorodental health of their children up to six years old. Zahedan J Res Med Sci 2010;12(4):43-8. [Full Text in Persian]

7. Vanobbergen J, Lesaffre E, Garcia-Zattera MJ, Jara A, Martens L. Caries patterns in primary dentition in 3-5- and 7years-old children: spatial correlation and preventive consequences. N Engl Caries Res 2007;41(1):16-25.

8. Mani SA, Aziz AA, John J, Ismail NM. Knowledge, attitude and practice of oral healthpromoting factors among caretakers of children attending day-care centers in Kubang Kerian, Malaysia: A preliminary study. N Engl J Indian Soc Pedod Prev Dent 2010;28(2):78-83.

9. Hooley M, Skouteris H, Boganin C, Satur J, Kilpatrick N. Parental influence and development of dental caries in children aged 0-6 years: A systematic review of the literature. J Dent 2012;40(11):873-85.

10. Hooley M, Skouteris H, Boganin C, Sature J, Kilpatric N. Parental influence and the development of dental caries in children aged 0-6 years: a systematic review of the literature. Journal of Dentistry 2012; 40(11):873-85

11. Baginska J, Rodakowska E. Knowledge and practice of caries prevention in mother form Bialystok, Poland. International Journal of Collaborative Research on Internal edicine \& Public Health 2012; 4(4):256-66.

12. Al-Ayed IH. Mothers' knowledge of child health matters: Are we doing enough? Journal of Family and Community Medicine 2010; 17(1):22-8.

13. Morris AJ, Steele J, White DA. The oral cleanliness and periodontal health of UK adults in 1998. Br Dent J. 2001; 191(4):186-92 
14. Hollister MC, Marion G Anema MG. Health behavior models and oral health: A Review. J Dent Hyg.2004;78(3):100-120.

15. Armitage CJ, Conner M. Efficacy of the theory of planned behaviour: A meta-analytic review. Br J Soc Psycho. 2001 Dec;40(4): 471-499.

16. Bashirian S, Haidarnia A, Allahverdipour H, Hajizadeh E. Application of Theory of Planned Behavior in Predicting Factors of Substance Abuse in Adolescents. JFUMS 2012; 2: $156-62$

17. Lazuras L, Eiser JR, Rodafinos A. Predicting Greek adolescents' intentions to smoke: A focus on normative processes. Health Psychol 2009; 28: 770-8.

18. Van De Ven MO, Engels RC, Otten R, Van Den Eijnden RJ. A longitudinal test of the theory of planned behavior predicting smoking onset among asthmatic and nonasthmatic adolescents. J Behav Med 2007; 30: 435-45
19. Mirzaei Alavijeh M, Mazloomy S, Yassini M, Askarshahi M, \& Jalilian F. (2014). The Role of Fathers in Prevention of Children Tendency toward Addictive Drugs: An Application of Theory of Planned Behavior. Journal of Military Medicine. Period 3. Volume 4. Winter (2014). 249-258

20. Hosseini N, Morrowati Sharifabad M A, Rahaii Z, Fallazadeh Abarghii H, \& Haerian A. (2018). A Survey of Predictors of Oral and Dental Care in Pregnant Women in Yazd: Based on the Theory of Planned Behavior. The Journal of Toloo-eBehdasht of Yazd. 17 $7^{\text {th }}$ Year. First Volume.

21. Peyman N. \& Samiee Roudi Kh. (2015). The Effect of Education Based on the Theory of Planned Behavior on Caries Prevention of Permanent Teeth in Fifth Grade Students in Khaf City. Journal of Mashhad Dental School. Period 39. Volume 2. 123-126 